\title{
Model wsparcia szkolnictwa zawodowego. Budowanie lokalnej sieci współpracy wyzwaniem lokalnej i regionalnej polityki edukacyjnej
}

\section{Streszczenie}

Artykuł jest próbą prześledzenia zmian zachodzących w szkolnictwie zawodowym w Polsce ze szczególnym uwzględnieniem możliwości lokalnych i regionalnych działań wspierających szkolnictwo zawodowe. Propozycje zawarte w tekście wynikają z eksperckich doświadczeń autorki związanych z realizacją projektów na rzecz wsparcia szkolnictwa zawodowego.

Prezentowany model wsparcia szkolnictwa zawodowego jest obecnie realizowany przez Białostocką Fundację Kształcenia Kadr ${ }^{1}$ na terenie miasta Białegostoku i powiatu białostockiego jako Centrum Kompetencji Białostockiego Obszaru Funkcjonalnego (BOF). Doświadczenia w realizacji projektu i jego skuteczność są na tyle uniwersalne, że projekt będzie wdrażany na terenie całego województwa podlaskiego. Może stanowić też wzorzec dla samorządowych jednostek publicznych prowadzących szkoły zawodowe.

Słowa kluczowe: modernizacja szkolnictwa zawodowego, dualny system kształcenia, luka kompetencyjna, popytowe doradztwo zawodowe, kształcenie ustawiczne, partnerstwo lokalne

\footnotetext{
1 Białostocka Fundacja Kształcenia Kadr od lat 90. XX w. bierze udział w badaniach lokalnego rynku pracy oraz upowszechniania wiedzy na temat potrzeb pracodawców w zakresie aktualnego i przyszłego popytu na kompetencje pracowników. Fundacja na podstawie prowadzonych badań i analiz rynku pracy wspiera instytucje oświatowe, przekazując im wiedzę na temat aktualnych i przyszłych potrzeb kompetencyjnych pracodawców. Wspiera zarządzanie instytucjami systemu oświaty, budowanie systemu zapewnienia jakości kształcenia w instytucjach systemu oświaty. Prowadzi doradztwo zawodowe dla uczestników kształcenia ustawicznego.
} 


\title{
Model of Supporting Vocational Education: Developing a Local Co-Operation Network as a Challenge to the Local and Regional Educational Policy
}

\begin{abstract}
The article is an attempt to trace the changes taking place in vocational education in Poland, paying special attention to the possibilities of local and regional activities supporting vocational education. The conclusions presented in the text result from the author's expert experience related to the implementation of projects to support vocational education.

The presented model of support for vocational education is currently carried out by the Bialystok Human Resources Training Foundation in the city of Białystok and Białystok Poviat as the Competence Centre of the Białystok Functional Area. The experience in the implementation of the project and its effectiveness is so universal that the project will be implemented throughout the Podlasie Voivodeship. It can also be a model for local government units running vocational schools.

Keywords: modernization of vocational education, dual education system, competence gap, demanding career counseling, lifelong learning, local partnership
\end{abstract}

Zmiany w szkolnictwie zawodowym wynikają przede wszystkim z potrzeb rynku pracy. Jak podkreśla się w literaturze, głównym wyznacznikiem zmian edukacji zawodowej w Polsce jest dostosowanie profilu pracowników do potrzeb sektorów generujących wzrost gospodarczy (Symela, 2009). Znaczący wpływ ma również rozwój technologiczny oraz członkostwo w UE, wymuszające dostosowanie krajowej gospodarki do wymogów międzynarodowej konkurencji i globalizacji (ibidem). Według S. Myszki (2009; 88-89), można wyróżnić następujące czynniki zmian w krajowym systemie edukacji ustawicznej:

1) potrzeby gospodarki i rynku pracy,

2) strategie rozwoju kraju, regionów i edukacji,

3) priorytety Ministerstwa Edukacji Narodowej skupiające się przede wszystkim na poprawie jakości kształcenia,

4) nowe podstawy kształcenia ogólnego,

5) projekty Europejskiego Funduszu EFS, w tym programu operacyjnego Kapitał Ludzki (PO KL).

Podstawowym aktem prawnym regulującym sprawy oświatowe w Polsce jest ustawa z dania 7 września 1991 r. o systemie oświaty (Dz. U., 2004). Jak wynika z przepisów, szkoły zawodowe mogą być zakładane i prowadzone przez: 
1) jednostkę samorządu terytorialnego (JST),

2) inną osobę prawną,

3) osoby fizyczne.

Jednostki samorządu terytorialnego mogą zakładać i prowadzić jedynie szkoły i placówki publiczne. Ustawa dodatkowo przewiduje możliwość zakładania i prowadzenia szkół kształcących w zawodach przez odpowiedniego ministra. Zakładanie i prowadzenie szkół zawodowych, z wyjątkiem szkół i placówek o znaczeniu regionalnym i ponadregionalnym, należy do zadań własnych powiatu. W roku szkolnym 2017/2018 (Oświata i wychowanie w roku szkolnym 2017/2018) funkcjonuje 1905 techników i techników uzupełniających, z czego 1706 o statusie szkół publicznych. Jest też 269 szkół artystycznych dających uprawnienia zawodowe. Edukacja na poziomie zawodowym jest więc przede wszystkim domeną jednostek samorządu terytorialnego na poziomie powiatu.

Obecnie mamy do czynienia z sytuacją, w której gospodarka zaczyna poważnie odczuwać braki kandydatów do pracy mających przygotowanie zawodowe - absolwentów szkół zawodowych i techników. Taki stan rzeczy może być związany z degradacją szkolnictwa zawodowego i obiegową opinią, że szkoły zawodowe są szkołami drugiej kategorii, do których pretendują uczniowie niemający szans dostania się do liceów ogólnokształcących. Kolejny czynnik to likwidacja szkół zawodowych i przyzakładowych, które kształciły kadry na potrzeby dużych zakładów pracy. W $2005 \mathrm{r}$. było 5009 szkół zawodowych, w 2015 r. - 4026 (Analiza szkolnictwa..., 2017). Tylko w województwie podlaskim w latach 2005-2009 zamknięto 6 zasadniczych szkół zawodowych, 11 techników oraz 10 szkół policealnych (Juchnicka, 2015).

Brak absolwentów szkół zawodowych może być również związany z niżem demograficznym i starzeniem się społeczeństwa - w tym odchodzeniem na wcześniejsze emerytury fachowców z wykształceniem zawodowym. Ponadto przyczyną braku specjalistów zawodowych może być emigracja Polaków po 2004 r. do krajów Unii Europejskiej, gdzie możliwości zarobkowe na takich samych stanowiskach, co w Polsce zasadniczo się różnią. W roku 2018 w Polsce obowiązująca stawka płac minimalnych wynosi 2100 PLN brutto (ok. 470 EUR) w wymiarze miesięcznym i 13,70 PLN brutto za godzinę. Tabela 1 obrazuje płace minimalne w poszczególnych krajach UE. 
Tabela 1. Płaca minimalna w poszczególnych państwach UE w latach 2017-2018 (w EUR brutto)

\begin{tabular}{|c|c|c|}
\hline \multirow{2}{*}{ Państwo } & \multicolumn{2}{|c|}{ Płaca minimalna } \\
\hline & Rok 2017 & Rok 2018 \\
\hline Luksemburg & 2003 & 2053 \\
\hline Irlandia & 1563 & 2053 \\
\hline Holandia & 1530 & 1540 \\
\hline Belgia & 1532 & 1558 \\
\hline Niemcy & $8,84 / \mathrm{h}$ & $9,5 / \mathrm{h}$ \\
\hline Francja & 1480 & 1500 \\
\hline Wielka Brytania & $7,5 / \mathrm{h}$ & $8 / h$ \\
\hline Hiszpania & 826 & 826 \\
\hline Stowenia & 795 & 800 \\
\hline Malta & 736 & 1135 \\
\hline Grecja & 684 & 684 \\
\hline Portugalia & 650 & 670 \\
\hline Estonia & 450 & 470 \\
\hline Polska & 453 & 470 \\
\hline Słowacja & 425 & 450 \\
\hline Chorwacja & 414 & 418 \\
\hline Węgry & 364 & 372 \\
\hline Czechy & 368 & 378 \\
\hline Łotwa & 380 & 390 \\
\hline Litwa & 370 & 380 \\
\hline Czarnogóra & 288 & 288 \\
\hline Rumunia & 250 & 266 \\
\hline Serbia & 249 & 243 \\
\hline Bułgaria & 230 & 230 \\
\hline Macedonia & 235 & 235 \\
\hline
\end{tabular}

Źródło: opracowanie na podstawie danych z www.wynagrodzenia.pl

\section{Zmiany w kształceniu zawodowym na poziomie centralnym}

W ramach zmian ustroju szkolnego od roku szkolnego 2017/2018 wprowadzona została trzyletnia branżowa szkoła I stopnia dla młodzieży (Ustawa z dnia 14 grudnia 2016). Kształcenie w branżowych szkołach I stopnia będzie się odbywało w zawodach, dla których przewidziane zostało kształcenie w tym typie szkoły. Z założenia wszystkie zawody przyporządkowane do tego typu szkoły będą zawodami jednokwali- 
fikacyjnymi, a część z nich będzie miała kwalifikację wspólną z zawodem nauczanym w technikum. Dzięki takiemu rozwiązaniu absolwenci branżowej szkoły I stopnia będą mogli kontynuować naukę w branżowej szkole II stopnia w celu uzyskania dyplomu technika oraz uzyskania wykształcenia średniego branżowego. W branżowych szkołach pierwszego stopnia będą zachowane dotychczasowe klasy wielozawodowe. W związku z tym, że pierwsi absolwenci ukończą szkołę branżową I stopnia w 2020 r., w roku szkolnym 2020/2021 rozpoczną działalność branżowe szkoły zawodowe II stopnia, dające możliwość kontynuacji nauki absolwentom szkół branżowych I stopnia. Do branżowej szkoły II stopnia będą przyjmowani absolwenci branżowej szkoły I stopnia, którzy odebrali kształcenie w zawodzie, w którym wyodrębniono kwalifikację wspólną dla zawodu nauczanego w danej branżowej szkole II stopnia. Ukończenie szkoły branżowej II stopnia umożliwi uzyskanie dyplomu potwierdzającego kwalifikacje zawodowe, co wiąże się ze zdaniem egzaminu potwierdzającego kwalifikacje w danym zawodzie, co z kolei przekłada się na uzyskanie wykształcenia średniego branżowego.

Absolwenci branżowej szkoły II stopnia będą mieli możliwość przystąpienia do egzaminu maturalnego z języka polskiego, matematyki i języka obcego na poziomie podstawowym. W wypadku absolwentów branżowej szkoły zawodowej pierwszego stopnia kształcący się w zawodach, dla których nie jest przewidziane kształcenie w branżowej szkole II stopnia, będą mogli podjąć pracę lub kontynuować naukę w liceum ogólnokształcącym dla dorosłych oraz na kwalifikacyjnych kursach zawodowych organizowanych przez szkoły zawodowe CKP (Centra Kształcenia Praktycznego), CKU (Centra Kształcenia Ustawicznego).

Dodatkowym rozwiązaniem, które zostało wprowadzone w nowelizacji ustawy Prawo oświatowe z 14 grudnia 2016 r. w art. 47.1 rozporządzeniem ministra właściwego do spraw oświaty, są minimalne godziny z zakresu doradztwa zawodowego oraz warunki w zakresie realizacji doradztwa zawodowego. Istotne jest, że doradztwo zawodowe będzie obejmowało uczniów klas VII i VIII szkoły podstawowej, branżowej szkoły pierwszego stopnia, liceum ogólnokształcącego i technikum. W art. 292.1 ustawy przepisy wprowadzające ustawę - Prawo oświatowe $z 14$ grudnia 2016 r. przewidziano, że zajęcia z zakresu doradztwa zawodowego są realizowane na podstawie programu przygotowanego przez nauczyciela realizującego te zajęcia i dopuszczonego przez dyrektora szkoły po zasięgnięciu opinii rady pedagogicznej. Program ten powinien zawierać informacje o zawodach, kwalifikacjach i stanowiskach pracy oraz możliwościach uzyskania kwalifikacji zgodnych z potrzebami rynku pracy i predyspozycjami zawodowymi. Wsparciem w przygotowaniu doradztwa zawodowego w szkołach jest projekt w ramach Programu Operacyjnego Wiedza Edukacja Rozwój „Efektywne 
doradztwo edukacyjno-zawodowe dla dzieci, młodzieży i dorosłych" realizowany przez Ośrodek Rozwoju Edukacji².

\section{Modernizacja szkolnictwa zawodowego na poziomie lokalnym}

Warte zastanowienia i głębszej refleksji są nie tylko rozwiązania centralne, wynikające ze zmian ustawowych, które mają służyć modernizacji szkolnictwa zawodowego, ale także istotne jest podkreślenie roli czynników lokalnych, w tym interesariuszy lokalnych. Mogą oni mieć znaczny wpływ na kształt szkół zawodowych i dopasowanie, a nawet „szycie na miarę” oferty kształcenia do potrzeb lokalnego rynku pracy.

Proces przeobrażania się szkolnictwa zawodowego powinien mieć na celu kształcenie w takich zawodach, które dają szansę na zatrudnienie absolwentów szkół zawodowych na rynku lokalnym, a tym samym mają wpływ na rozwój gospodarczy regionu. Proces ten nie jest możliwy bez wzmożonej aktywności organów administracji publicznej będących właścicielami i organami nadzorującymi szkoły zawodowe, czyli starostów oraz prezydentów w wypadku miast funkcjonujących na prawach powiatu - powiatów grodzkich. Kształcenie zawodowe dopasowane do wymagań lokalnego rynku pracy powinno być realizowane w ścisłej współpracy z innymi lokalnymi interesariuszami. Wydaje się, że kształtowanie lokalnej polityki edukacyjnej nie może się obyć bez takich podmiotów jak: Powiatowe Rady Rynku Pracy i Wojewódzkie Rady Rynku Pracy, lokalni przedsiębiorcy, uczelnie wyższe funkcjonujące w regionie, lokalne organizacje pozarządowe zajmujące się problematyką zatrudnienia, cechy rzemieślnicze, izby przemysłowo-handlowe, instytucje kształcenia ustawicznego. Dlatego na uwagę zasługuje tworzenie lokalnych grup wsparcia - jako podmiotów wspierających modernizację szkolnictwa zawodowego. Istotne jest również, aby modernizacja szkolnictwa zawodowego była osadzona w strategicznych rozwiązaniach zaplanowanych w dokumentach istotnych z perspektywy rozwoju regionalnego, do których przede wszystkim należy Strategia Rozwoju Regionalnego.

Na podstawie diagnozy „Bilans Kapitału Ludzkiego 2010-2015” wskazano, że jednym z głównych problemów zgłaszanych obecnie przez pracodawców jest „trudność ze znalezieniem odpowiednich pracowników" (Górniak, 2015). Jednocześnie okazuje się, że trudności rekrutacyjne zgłaszane przez pracodawców nie wynikają $\mathrm{z}$ istniejących niedoborów pracowników w najbardziej poszukiwanych zawodach

2 Więcej informacji na temat działań wspierających szkolnictwo zawodowe Ośrodka Wspierania Edukacji można znaleźć na stronie www. ore.edu.pl 
(Dane GUS..., 2017). Pracodawcy, zgłaszając braki u osób kandydujących do pracy, podkreślają braki wynikające z nieodpowiednich kompetencji zarówno zawodowych, jak i kompetencji miękkich, doświadczenia i chęci do pracy. Jednym ze sposobów identyfikacji kompetencji pracowników jest organizacja systemu edukacji zawodowej w ścisłej współpracy z otoczeniem, a przede wszystkim lokalnymi przedsiębiorcami. Tak więc istotnym elementem reformowania szkolnictwa zawodowego jest dążenie do stworzenia systemu dualnego kształcenia, które funkcjonuje skutecznie od wielu lat w krajach zachodnich. Dążenie do jak największego upraktycznienia kształcenia zawodowego wynika z potrzeby realizacji zaleceń Komisji Europejskiej sformułowanych w odniesieniu do polityki oświatowej państw członkowskich w opublikowanym w 2013 r. komunikacie w sprawie bezrobocia osób młodych (Komunikat Komisji Europejskiej..., 2013). W wypadku Polski zalecenia te dotyczą m.in. zwiększenia dostępności przyuczania do zawodu i uczenia się poprzez praktykę oraz zacieśnienia współpracy szkół i pracodawców. W dokumencie tym podkreśla się, że państwa „Z ugruntowanymi systemami przyuczania do zawodu i rozbudowanymi możliwościami uczenia się poprzez praktykę mają tendencję do osiągania lepszych wyników w zakresie ułatwiania przejścia od edukacji do zatrudnienia i utrzymania niskiego poziomu bezrobocia osób młodych". W centrum debaty na forum Unii Europejskiej znalazły się kwestie dotyczące promowania uczenia się poprzez praktykę w miejscu pracy, w tym m.in. przyuczania do zawodu i dwutorowych systemów kształcenia, rozumianych jako „połączenie przyuczenia do zawodu w danym przedsiębiorstwie oraz kształcenia zawodowego w instytucji oświatowej”.

Dualny model kształcenia zawodowego jest to forma kształcenia wysoko oceniana w Unii Europejskiej, a doświadczenia niemieckie uważane są za najbardziej efektywne (Krajowa Konferencja, 2017). Model dualnego kształcenia zakłada, że uczniowie szkół zawodowych będą się uczyli zawodu w sposób jak najbardziej praktyczny. Może to się wiązać $\mathrm{z}$ takim rozwiązaniem, że uczeń spędza dwa dni w szkole, gdzie ma okazję na teoretyczne zapoznanie się i wprowadzenie w arkana zawodu, natomiast kolejne trzy dni spędza u pracodawcy pod okiem nauczyciela zawodu (najlepiej osoby zatrudnionej w danej firmie). To rozwiązanie daje okazję na poznanie w praktyce tajników zawodowych, wykonywanie czynności, zadań zawodowych w środowisku najbardziej zbliżonym do realnego środowiska pracy, w którym po skończeniu szkoły absolwent może podjąć zatrudnienie. Pionierem kształcenia dualnego w Polsce jest rzemiosło. Jednocześnie takie firmy jak Solaris, Volkswagen Poznań i wiele innych rozpoczęły praktyczną naukę zawodu w miejscu pracy. Współpraca między pracodawcami oraz szkołami zawodowymi odbywa się najczęściej w sposób niesformalizowany i jest wciąż jeszcze niezadowalająca. Tymczasem w państwach, w których funkcjonuje dualny system kształcenia, stopa bezrobocia wśród młodych jest zdecydowani niższa niż 
w Polsce, gdzie system ten obejmuje mniej niż 20 proc. uczniów szkół zawodowych. W Niemczech, gdzie prawie 70 proc. uczniów szkół zawodowych uczy się w systemie dualnym, poziom bezrobocia wśród osób poniżej 25. roku życia wynosi 7,2 proc., podczas gdy w Polsce 17 proc. (ibidem).

„Zielone światło” dla wprowadzania modelu dualnego kształcenia daje duże możliwości władzom lokalnym - organom właścicielskim szkół, które powinny się kierować kilkoma priorytetami. Po pierwsze, zapewnieniem rozwoju lokalnych przedsiębiorstw, które powinny mieć dostęp do możliwie najlepiej wykształconej kadry. To bezpośrednio wiąże się z drugim elementem, a mianowicie zapobieganiem migracji młodych pracowników do innych regionów lub za granicę w poszukiwaniu pracy i możliwości rozwoju zawodowego. Dlatego też w skutecznym reformowaniu szkolnictwa zawodowego konieczna jest maksymalna współpraca władz lokalnych, lokalnych przedsiębiorców, zrzeszeń pracodawców, szkół (dyrektorów i kadry nauczycieli zawodu).

Trzeba z całą stanowczością zaznaczyć, że modernizacja szkół zawodowych nie może być dziełem samym w sobie, oderwanym od realiów lokalnych i regionalnych. Szkolnictwo zawodowe musi się opierać na potencjale regionalnej gospodarki. Głównym celem artykułu jest zaproponowanie modelu wsparcia szkolnictwa zawodowego, który może zostać przygotowany i wdrożony na podstawie ścisłej współpracy międzysektorowej różnych podmiotów funkcjonujących lokalnie i regionalnie. Podmiotom tym powinno zależeć na stworzeniu dobrej marki szkół zawodowych, która może realnie wpłynąć na rozwój potencjału gospodarczego regionu.

Instytucjonalnoprawną formułą wspierania szkolnictwa zawodowego na podstawie współpracy międzysektorowej są partnerstwa lokalne.

Inicjatorami partnerstw lokalnych mogą być osoby fizyczne - liderzy lokalni, którzy chcą aktywnie wpływać na swoje otoczenie gospodarcze, społeczne, edukacyjne, kulturalne. Mogą to być przedsiębiorcy, organizacje gospodarcze lub zawodowe, np. spółdzielnie, związki producentów, izby rzemieślnicze. Tego rodzaju partnerstwa w pierwszym rzędzie dążą do osiągania coraz większego wpływu na decyzje dotyczące gospodarki. Mogą skupiać się na promowaniu lokalnych wyrobów, zwiększeniu dostępności do rynków ponadlokalnych, wspieraniu inicjatyw przedsiębiorczych. W końcu inicjatorami partnerstw lokalnych mogą być instytucje publiczne, które zwykle początkowo koncentrują się na poprawie jakości infrastruktury i obiektów publicznych.

Artykuł 6 pkt 7 ustawy z dnia 20 kwietnia 2004 r. o promocji zatrudnienia i instytucjach rynku pracy (Dz. U., 2004) wskazuje, że „instytucją partnerstwa lokalnego jest grupa instytucji realizujących na podstawie umowy przedsięwzięcia i projekty na rzecz rynku pracy”. 
Skuteczność współpracy będzie miała przełożenie na tworzenie kierunków nauczania, które są wartościowe dla lokalnych przedsiębiorców i dają perspektywę pozyskania odpowiednich pracowników wyróżniających się kwalifikacjami zawodowymi istotnymi z perspektywy danego pracodawcy.

\section{Lokalne wsparcie szkolnictwa zawodowego - doświadczenia Centrum Kompetencji Białostockiego Obszaru Funkcjonalnego}

Zmiany w szkolnictwie zawodowym są przedsięwzięciem, które można traktować jak system naczyń połączonych, a jeden z elementów jest konsekwencją kolejnego. Mając na względzie modernizację szkolnictwa zawodowego z perspektywy działań lokalnych można zaproponować model wsparcia opierający się na następujących rozwiązaniach:

- badaniu potrzeb firm rynku lokalnego - wykrywaniu luki kompetencyjnej,

- doradztwie zawodowym opartym na modelu popytowym,

- zapewnieniu staży i kursów zawodowych uczniom wraz z certyfikowaniem nabytych w trakcie zajęć praktycznych kompetencji zawodowych,

- przygotowaniu programów rozwojowych szkół opartym na ścisłej współpracy z otoczeniem szkoły - lokalnymi firmami, instytucjami publicznymi, uczelniami wyższymi, organizacjami zrzeszającymi pracodawców, organizacjami pozarządowymi,

- opracowaniu systemu jakości szkolnictwa zawodowego - rodzaju klamry spinającej wszystkie wcześniejsze elementy procesu modernizacji,

- popularyzacji szkolnictwa zawodowego skierowanej do uczniów szkół gimnazjalnych i podstawowych, rodziców oraz szeroko rozumianego otoczenia szkoły.

\section{Badanie potrzeb firm rynku lokalnego}

Za pierwszy element modernizacji szkolnictwa zawodowego można uznać konieczność stałego badania i monitorowania potrzeb lokalnego rynku. Identyfikacja potrzeb firm związana jest z niwelowaniem luki kompetencyjnej na różnych poziomach. Po pierwsze, należy ustalić listę zawodów, wynikającą z podaży i popytu, analogicznie do rankingów zawodów nadwyżkowych i deficytowych oraz prognoz w zakresie zawodów przyszłości, adekwatnie do tak zwanych „starterów gospodarki” oraz branż kluczowych w poszczególnych regionach, z zastrzeżeniem, że metodologia powinna wykraczać poza dotychczasowe statystki rynku pracy generujące paradoksalne 
niedopasowanie deficytów i nadwyżek na poziomie zawodów (porównanie ofert pracy w PUP z osobami poszukującymi pracy w PUP), a także uwzględniać zmienne dotyczące migracji zarobkowej i szarej strefy oraz strukturalnego bezrobocia. Istotne jest również diagnozowanie niedopasowania faktycznych umiejętności kandydatów do pracy w danym zawodzie z potrzebami pracodawców w danej branży. Wyniki analizy „pierwszego poziomu” luki kompetencyjnej mogą tworzyć rekomendacje dla szkół zawodowych w zakresie otwierania i zamykania kierunków kształcenia w zawodzie. Rekomendacji tych nie należy jednak mylić $\mathrm{z}$ rankingami zawodów nadwyżkowych i deficytowych. Rankingi zawodów powstałe w efekcie badania luki kompetencyjnej powinny bowiem uwzględniać wyniki analizy tej luki na jej niższych, bardziej szczegółowych poziomach opisanych poniżej, przezwyciężając mankamenty rankingów funkcjonujących dziś na rynku pracy, które nie obrazują precyzyjnie faktycznych potrzeb kompetencyjnych pracodawców oraz faktycznej podaży kompetencji po stronie kandydatów do pracy. Dzieje się tak, ponieważ kategoria zawodu jest kategorią zbyt ogólną dla precyzyjnego dopasowania pracodawców z osobami poszukującymi pracy.

Kolejny poziom badań luki kompetencyjnej wiąże się z oceną poziomu kwalifikacji. Ukazuje on braki kompetencyjne osób posiadających dany zawód w zakresie określonych kwalifikacji składających się na ten zawód lub nowych kwalifikacji wykraczających poza ten zawód w systemie kształcenia (zgodnie z istniejącą podstawą programową) w sytuacji, gdy pracodawca wymaga dodatkowych kwalifikacji pracowników (wielozawodowe stanowiska pracy), jednak w zakresie węższym niż wynikającym z połączenia dwóch całych zawodów. Analiza wymaga konsultacji w zakresie oświatowych standardów kwalifikacji (tj. efektów kształcenia i treści programowych dla każdej kwalifikacji). Wyniki analizy „drugiego poziomu” luki kompetencyjnej mogą tworzyć rekomendacje dla szkół zawodowych w zakresie kreowania „nowych zawodów" i otwierania nowych kierunków kształcenia oraz w wymiarze doraźnym dla szkół zawodowych czy instytucji szkoleniowych kształcenia ustawicznego w zakresie tworzenia oferty Kwalifikacyjnych Kursów Zawodowych (KKZ) uzupełniających kwalifikacje absolwentów szkół uczących się „starych zawodów” (Rozporządzenie Ministra Edukacji Narodowej, 2012). Dodatkowo poprzez dostępną ofertę KKZ nastąpi otwarcie rynku pracy dla osób niekończących szkoły zawodowej w wypadku stanowisk pracy wymagających niepełnego zawodu, czyli pojedynczej kwalifikacji dostępnej także dla uczestników i absolwentów kształcenia ogólnego.

Trzeci poziom luki kompetencyjnej wiąże się z badaniem poziomu umiejętności, czyli elementów kwalifikacji zgodnie z systemem kwalifikacji w systemie oświaty. Analiza popytu na umiejętności rozumiane jako część kwalifikacji wymaga wnikliwej analizy i opisu stanowisk pracy charakterystycznych dla danej branży z zaangażo- 
waniem osób wykonujących pracę na tych stanowiskach - pracowników i mistrzów rozumiejących procesy pracy w konkretnym środowisku pracy, współpracujących z nauczycielami zawodu oraz instruktorami praktycznej nauki zawodu rozumiejącymi efekty kształcenia dla poszczególnych kwalifikacji wymaganych przez dane środowisko pracy. Wyniki analizy „trzeciego poziomu” luki kompetencyjnej BOF tworzą rekomendacje w zakresie oferty Kursów Umiejętności Zawodowych (KUZ).

Ze względu na fakt, że obecnie praktycznie nie istnieje rynek edukacyjny w zakresie KUZ, a ta forma kształcenia zawodowego będzie bardziej dostępna i popularna niż obecna wąska oferta KKZ ze względu na krótszy czas nauki (kilkumiesięczny KUZ jest kilkakrotnie krótszy niż trwający ok. półtora roku KKZ) oraz bardziej precyzyjne określenie zakresu doskonalenia, konieczne będzie opracowanie standardu edukacyjnego i egzaminacyjnego dla wybranych KUZ - adekwatnie do kwalifikacji kluczowych dla Białostockiego Obszaru Funkcjonalnego (BOF) określonych na podstawie dwóch pierwszych poziomów analizy luki kompetencyjnej BOF. Do określenia tych standardów katalogu wykorzystane będą standardy edukacyjne i egzaminacyjne dla kluczowych czynności/zadań zawodowych opisane na stanowiskach pracy z udziałem pracowników i pracodawców oraz instruktorów praktycznej nauki zawodu w ramach czwartego poziomu analizy luki kompetencyjnej, opisanego poniżej. Ten poziom luki kompetencyjnej po stronie podaży będzie badany w zakresie aspiracji i potrzeb edukacyjnych kandydatów do systemu kształcenia zawodowego oraz absolwentów szkół zawodowych występujących w roli nowych pracowników audytowanych firm.

Ostatnim poziomem badań luki kompetencyjnej może być analiza opisu czynności/zadań zawodowych składających się na umiejętności zawodowe (adekwatne do KUZ), z których z kolei składają się kwalifikacje zawodowe (adekwatne do KKZ). Podział zawodu na czynności (zadania) zawodowe zgodny jest ze światowymi trendami edukacyjnymi oraz metodologią MES (Modules of Employable Skills - Modułowy System Kształcenia). Opis czynności zawodowych wraz ze standardem edukacyjnym i egzaminacyjnych dla poszczególnych czynności musi być przygotowany przez praktyków wykonujących te czynności w środowisku pracy oraz specjalistów ds. edukacji zawodowej doświadczonych w określaniu efektów kształcenia w MES. Opisane czynności poprzez ich popytowe zestawienie tworzą najlepsze i najpraktyczniejsze standardy edukacyjne dla KUZ. Czynności zawodowe, ze względu na swój praktyczny i analityczny podstawowy charakter kształtowane są tylko i wyłącznie w środowisku pracy poprzez ich wykonywanie z możliwością pomiaru efektu czynności (efektu pracy). Dlatego też najlepszą formą edukacyjną w tym wymiarze luki kompetencyjnej są praktyki i staże, których program składany jest z wybranych czynności adekwatnie do realnego „potencjału edukacyjnego” firmy przyjmującej 
na staż (wyposażenie stanowiska edukacyjnego, narzędzia i urządzenia, procesy technologiczne i wytwórcze). Kształtowanie umiejętności na poziomie czynności zawodowych może też następować na krótkich praktycznych kursach umożliwiających uzyskanie kompetencji w zakresie określonych czynności zawodowych (ibidem). Wyniki analizy „czwartego poziomu” luki kompetencyjnej tworzą rekomendacje w zakresie oferty praktyk i staży zawodowych uzupełniających kształcenie w zawodzie - jako element lub uzupełnienie podstawy programowej w wybranych zawodach, adekwatnie do zakresu zdiagnozowanej luki kompetencyjnej oraz oferty krótkich praktycznych kursów umożliwiających uzyskanie wiedzy, umiejętności i kwalifikacji zawodowych w zakresie określonych czynności zawodowych.

Identyfikowanie luki kompetencyjnej na różnych poziomach daje szansę na optymalizację systemu kształcenia poprzez dopasowanie formy kształcenia zawodowego do poziomu i szczegółowości zdiagnozowanej luki kompetencyjnej. Podejście to zwiększa efektywność kształcenia zawodowego poprzez skuteczniejsze zarządzanie procesem edukacji w kontekście kosztów edukacji i czasu jej trwania. W ten sposób system ma szanse stać się elastyczny, precyzyjnie reagując na zdiagnozowane potrzeby rynku oraz faktyczną podaż kompetencji kreowaną przez absolwentów systemu kształcenia zawodowego, a także systematycznie monitorowane i metodycznie prognozowane możliwości edukacyjne, predyspozycje zawodowe i aspiracje aktualnych czy potencjalnych uczestników tego systemu.

Oprócz kompetencji o charakterze zawodowym nie mniej istotne są tak zwane kompetencje personalne i społeczne. Zgodnie z Podstawą Programową Kształcenia Zawodowego (Rozporządzenie Ministra Edukacji Narodowej, 2017) to: przestrzeganie zasad kultury i etyki, kreatywność i konsekwencja w realizacji zadań, umiejętność planowania działań i zarządzania czasem, umiejętność przewidywania skutków podejmowanych działań, świadomość ponoszenia odpowiedzialności za podejmowane działania, otwartość na zmiany, umiejętność stosowania technik radzenia sobie ze stresem, umiejętność aktualizowania wiedzy i doskonalenia umiejętność zawodowych, przestrzeganie tajemnicy zawodowej, negocjowanie warunków porozumień, komunikatywność, umiejętność stosowania metod i technik rozwiązywania problemów, umiejętność współpracy w zespole.

Wydaje się oczywiste, że szkoły w badaniach luk kompetencyjnych i potrzeb firm powinny liczyć na partnerów zewnętrznych. Sama szkoła nie ma tego rodzaju możliwości. Badania w tym zakresie mogą być wspierane np. przez lokalne organizacje pozarządowe zajmujące się badaniem potencjału rynku pracy. Dużym wsparciem mogą też być uczelnie wyższe. Analizy tego rodzaju prowadzą też powiatowe i wojewódzkie urzędy pracy. 


\section{Doradztwo zawodowe oparte na modelu popytowym}

Analiza potrzeb pracodawców przekłada się na kolejny punkt w modernizacji szkolnictwa zawodowego, tj. przygotowanie doradztwa zawodowego opartego na modelu popytowym, które powinno być oferowane uczniom już na etapie szkoły gimnazjalnej czy podstawowej. Różnica pomiędzy powszechnie dostępnym modelem doradztwa zawodowego a modelem doradztwa popytowego jest zasadnicza. Dotychczasowe doradztwo zawodowe opiera się na analizie przede wszystkim potencjału ucznia i jego aspiracji zawodowych. Doradcy zawodowi nie przedstawiają zwykle realnych informacji co do lokalnego rynku pracy. Nie dysponują konkretną wiedzą istotną dla doradztwa popytowego opartego na potencjale firm, możliwościach zatrudnienia nowego personelu, możliwościach tworzenia atrakcyjnych miejsc pracy dających perspektywy rozwoju pracownika. Tymczasem doradztwo popytowe zakłada inną percepcję, nie koncentrując się wyłącznie na poziomie ucznia (na podstawie jego zainteresowań i umiejętności), ale opiera się w dużej mierze na potencjale i potrzebach firmy. Doradca dysponuje informacjami o zarobkach na danym stanowisku, wymaganiach i możliwościach rozwoju. Przedstawia konkretne oczekiwania firm związane $z$ pracą na danym stanowisku. Doradztwo popytowe przesuwa punkt ciężkości z doradztwa opartego na aspiracjach uczniów i ich rodziców na doradztwo skoncentrowane na realnych możliwościach rynku pracy.

Wspieranie młodzieży w podejmowaniu decyzji edukacyjno-zawodowych na podstawie racjonalnych przesłanek, tak by były one adekwatne zarówno do predyspozycji uczniów, jak i wymagań rynku pracy, jest aktualnym wyzwaniem systemu edukacji.

\section{Zapewnienie staży i kursów zawodowych uczniom wraz z certyfikowaniem nabytych w trakcie tych zajęć praktycznych kompetencji zawodowych}

Zdiagnozowanie potrzeb firm oraz doradztwo kompetencyjne skierowane do uczniów dają podstawę do stworzenia kolejnego elementu wsparcia polegającego na przygotowaniu programów kursów i staży zawodowych. Celem tego rodzaju dodatkowych form edukacyjnych powinno być lepsze przygotowanie ucznia do pracy na danym stanowisku i sprostanie dodatkowym wymaganiom, jakie stawiają pracodawcy. Program tego rodzaju kursów i staży powinien być przygotowany w ścisłej współpracy z przedstawicielami firm. Przykładem mogą być kursy spawalnicze uzupełniające w zawodach takich jak technik mechanik, mechanik, mechanik pojazdów samochodowych czy staże zagraniczne przygotowujące do pracy w zawodzie technik hotelarz i oparte przede wszystkim na możliwości nauki języka 
obcego w miejscu pracy. W tym wypadku dużą rolę może odgrywać uczestnictwo w wymianach uczniów, jakie daje program Erasmus. Ważnym elementem odbytych kursów i staży powinna być certyfikacja nabytych kompetencji, czyli potwierdzenie, że uczeń w trakcie odbywania zajęć nabył konkretne umiejętności. Zaproponowane kursy mogą być krótszą formą niż kursy kształcenia zawodowego (KKZ).

\section{Przygotowanie programów rozwojowych szkół na podstawie ścisłej współpracy z otoczeniem szkoły - lokalnymi firmami, instytucjami publicznymi, uczelniami wyższymi, organizacjami zrzeszającymi pracodawców, organizacjami pozarządowymi}

Programy rozwojowe (strategie rozwoju szkoły) są dokumentami strategicznymi, których konieczność przygotowania wynika z Rozporządzenia Ministra Edukacji Narodowej z dnia 27 października 2009 r. w sprawie nadzoru pedagogicznego (Rozporządzenie Ministra Edukacji Narodowej, 2009). Dyrektor szkoły lub placówki prowadzącej kształcenie zobowiązany jest do opracowania programu i harmonogramu poprawy efektywności kształcenia lub wychowania. Program taki powinien uwzględniać perspektywę pięciu lat. Należy też przygotować programy roczne dające możliwość weryfikacji realizacji celów zaplanowanych w dłuższej perspektywie. Wskazuje się, aby programy rozwojowe były ściśle budowane we współpracy z najbliższym otoczeniem i interesariuszami szkoły, co daje realną możliwość wpływu na pozytywną zmianę w szkolnictwie. Istotne jest też, aby programy wpisywały się w strategie lokalne, regionalne, państwa i Europy. Projekty te powinny również:

- wynikać z diagnozy identyfikującej problemy i potrzeby,

- zawierać cele jednoznacznie zdefiniowane i konkretne,

- mieć przypisany i wyodrębniony budżet zadaniowy,

- być zaplanowane w czasie - posiadać harmonogram,

- być ukierunkowane na efekty - przewidywać rezultat (Jas i Łysak, 2009).

\section{Jakość kształcenia w szkolnictwie zawodowym - procedura akredytacyjna}

Kolejnym elementem tworzącym model wsparcia szkolnictwa zawodowego jest stworzenie systemu zapewniającego podwyższenie jakości szkolnictwa zawodowego. Do tej pory nie został wypracowany uniwersalny model oceny i doskonalenia jakości kształcenia w szkolnictwie zawodowym. Dotychczasowe oceny i rankingi, którym poddają się szkoły zawodowe, są oparte przede wszystkim na kryterium zdawalności przez uczniów egzaminów zewnętrznych. Wydaje się, że jest to kryterium 
niewystarczające do wiarygodnego i sprawiedliwego oceniania wysiłku szkoły włożonego w zapewnienie wysokiej oceny jakości. Wypracowanie modelu zapewnienia oceny i doskonalenia kształcenia zawodowego może być istotnym elementem wspierającym rozwój szkół zawodowych i ich potencjał. Wzorce do wypracowania takiego modelu można czerpać między innymi z doświadczeń Państwowej Komisji Akredytacyjnej, która od lat już funkcjonuje w ramach dbałości o jakość szkolnictwa wyższego. Do zadań komisji należy m.in. opiniowanie jakości nauczania i wydawanie uprawnień do prowadzenia studiów na danym kierunku, a także dokonywanie oceny programowej. PKA sprawdza także kompetencje nauczycieli akademickich i przestrzeganie warunków prowadzenia studiów ${ }^{3}$.

W przygotowaniu systemu akredytacji i oceny szkół zawodowych wiodącą rolę powinny odgrywać organy prowadzące szkoły zawodowe. Ich rola jest istotna z perspektywy doboru partnerów zainteresowanych rozwojem szkolnictwa zawodowego, a jednocześnie zapewniających merytoryczny wkład w przygotowanie systemów akredytacji. Podmiotami wspomagającymi mogą być organizacje pozarządowe, uczelnie wyższe, podmioty wspierające lokalny rynek pracy, przedsiębiorcy.

Stworzenie systemu akredytacji powinno być traktowane jako narzędzie poprawy funkcjonowania szkoły. Istotne jest wypracowanie narzędzi i kryteriów oceny jakości kształcenia. W procesie akredytacji istotne jest porównanie wypracowanych standardów pozwalających na ocenę jakości kształcenia ze stanem jakości kształcenia w danej placówce.

Ważny jest również skład komisji akredytacyjnej zaproponowany przez organ prowadzący. Powinien on zapewnić udział różnych podmiotów i instytucji, np. organów prowadzących szkołę, przedstawicieli kuratorium, przedstawicieli uczelni wyższych, instytucji rynku pracy, organizacji pozarządowych, a przede wszystkim grona ekspertów wywodzących się z różnych branż. Eksperci powinni być tak dobrani, aby reprezentowali poszczególne kierunki kształcenia. Powinni też reprezentować lokalnych przedsiębiorców, co daje rękojmię znajomości lokalnych uwarunkowań, jeśli chodzi o potrzeby kadrowe w poszczególnych branżach. Podobnie jak w doświadczeniach Państwowej Komisji Akredytacyjnej ocena szkoły mogłaby się opierać na stworzeniu kryteriów oceny instytucjonalnej i oceny programowej. W wypadku oceny instytucjonalnej za istotne należy uznać następujące kryteria:

- posiadanie opracowanej strategii/ programu rozwojowego szkoły,

- posiadanie wewnętrznego systemu zapewnienia jakości i doskonalenia jakości kształcenia,

3 Polska Komisja Akredytacyjna funkcjonuje w ramach przewidzianych w ustawie $\mathrm{z}$ dnia 27 lipca 2005 r. Prawo o szkolnictwie wyższym, aktach wykonawczych oraz „Europejskich standardach i wskazówkach dotyczących zapewnienia jakości w Europejskim Obszarze Szkolnictwa Wyższego”. 
- zapewnienie narzędzi wspierających uczniów w procesach uczenia się i doskonalenia jakości kształcenia.

W wypadku oceny programowej jej kryteria mogą się koncentrować na:

- sprawdzeniu dostosowania kierunków kształcenia i ich programów nauczania do potrzeb rynku pracy oraz ich zgodności z dokumentami strategicznymi w skali lokalnej i regionalnej,

- polityce kadrowej,

- zapewnieniu infrastruktury dydaktycznej umożliwiającej realizację programu kształcenia i osiągnięcia przez uczniów zakładanych efektów kształcenia,

- skuteczności podejmowanych działań na rzecz ścisłej współpracy z lokalnymi pracodawcami, aż do wdrożenia dualnego modelu kształcenia zawodowego.

Ocena jakości funkcjonowania szkoły będzie wymagała przygotowania odpowiednich procedur. $W$ procedurze oceny mogą być uwzględnione np. przygotowanie raportu samooceny przez szkołę, wizyty w szkole i spotkania z kadrą nauczycielską, uczniami, opiekunami kształcenia zawodowego na poszczególnych kierunkach kształcenia oferowanego w szkole, spotkania z przedstawicielami lokalnych firm współpracujących ze szkołą, opracowanie raportu oceny przez zespół akredytujący, przekazanie raportu do szkoły, przedstawienie przez szkołę odpowiedzi na raport, opracowanie przez zespół akredytujący propozycji oceny wraz z uzasadnieniem, podjęcie decyzji co do oceny i podanie jej do publicznej wiadomości przez organ prowadzący.

Procedura samooceny powinna uwzględniać przygotowanie samooceny przez daną szkołę, istotnej z perspektywy oceny instytucjonalnej i kierunkowej. Podobnie jak przy procedurach stosowanych przez PKA należałoby przygotować szkołę na konieczność wizyt akredytacyjnych i spotkań z dyrekcją szkoły, nauczycielami, uczniami, lokalnymi przedsiębiorcami współpracującymi ze szkołą.

Wyniki wszechstronnej oceny działań szkoły w celu zapewnienia jak najlepszego poziomu kształcenia mogą być podstawą do podejmowania strategicznych działań przez organ prowadzący, polegających na otwieraniu lub zamykaniu poszczególnych kierunków kształcenia, dofinansowaniu lub zmniejszeniu nakładów finansowych dla danej placówki, zmniejszeniu lub zwiększeniu potencjału kadrowego. Organy prowadzące będą miały też silne argumenty w razie chęci podejmowania działań zmierzających do silnego profilowania szkół i ich ubranżowiania.

Podawanie do publicznej wiadomości informacji na temat potencjału poszczególnych szkół oraz pokazywanie poziomu kształcenia, jaki mogą zapewnić szkoły na danym kierunku, może być czynnikiem wpływającym na wybór szkoły przez uczniów i ich rodziców. 


\section{Popularyzacja szkolnictwa zawodowego na poziomie szkół gimnazjalnych i podstawowych}

Za ostatni, ale bardzo istotny element wsparcia modernizacji szkolnictwa zawodowego można uznać działania popularyzatorskie. Szkolnictwo zawodowe wymaga dużych działań promocyjnych, za które odpowiadałyby nie tylko same szkoły zawodowe konkurujące często ze sobą o nowego ucznia. W popularyzację angażować się powinny też organy prowadzące i firmy zainteresowane pozyskaniem pracowników mających wykształcenie zawodowe. Uczniowie, ale też rodzice wpływający na wybór ścieżki kariery zawodowej swoich dzieci, często mają stereotypowe wyobrażenie o stanowiskach pracy wymagających zawodowego wykształcenia. Wiąże się to zarówno z myśleniem o warunkach pracy, jak i zarobkach. Promowanie szkolnictwa zawodowego to też szerokie upowszechnianie wiedzy na temat rynku pracy i zawodów deficytowych. Obecna sytuacja gospodarcza powinna sprzyjać większemu zaangażowaniu się pracodawców we współpracę ze szkołami w tym zakresie. Istotne jest pokazywanie dobrych praktyk, np. tworzenie funduszy stypendialnych dla najbardziej uzdolnionych uczniów na podstawie oceny ich zaangażowania w pracę na praktykach i stażach.

\section{$* * *$}

Wydaje się, że szkoły zawodowe stoją przed nową szansą rozwoju. Zaproponowany model wsparcia modernizacji szkolnictwa zawodowego może mieć charakter uniwersalny. Badania i diagnozy prowadzone w firmach związane z luką kompetencyjną mogą być bardzo pomocne przy doradztwie zawodowym w szkołach. Dają szansę na uzupełnienie kompetencji zawodowych uczniów jeszcze w procesie edukacji w szkole zawodowej, poprzez uzupełnianie edukacji kursami zawodowymi.

Na podstawie doświadczeń $\mathrm{w}$ realizacji modelu wsparcia szkolnictwa zawodowego Centrum Kompetencji Białostockiego Obszaru Funkcjonalnego można jednak dojść do wniosku, że szkoły zawodowe, żeby sprostać założeniom reformy ustrojowej przewidzianym przez ustawodawcę, muszą być wspierane przez szeroko rozumianych interesariuszy kształcenia zawodowego. Pozytywne zmiany są możliwe tylko, jeśli będą oparte na ścisłej współpracy całego środowiska lokalnego. 


\section{Bibliografia}

Analiza szkolnictwa zawodowego w województwie łódzkim. Badania wykonane na potrzeby interwencji w ramach Osi XI Edukacja, Kwalifikacje, Umiejętności Regionalnego Programu Operacyjnego Województwa Łódzkiego na lata 2014-2020(2017). Łódź: https://www. funduszeeuropejskie.gov.pl/media/39180/Analiza-sytuacji-szkolnictwa-zawodowego.pdf

Dane GUS za pierwszy kwartat 2017 roku wskazuja, że w roku szkolnym 2016/ 2017 ksztatca w kierunkach zawodowych 1663 zasadnicze szkoły zawodowe - 58673 uczniów i 1905 techników - 143162 uczniów, http://stat.gov.pl/obszary-tematyczne/edukacja/edukacja/ oswiata-i-wychowanie-w-roku-szkolnym-20162017,1,12.html

Dz. U. 2004, nr 256, poz. 2572 z późn. zm.

Górniak, J. (2015). Polski rynek pracy - wyzwania i kierunki działań, na podstawie badań bilans kapitału ludzkiego 2010-2015. Warszawa-Kraków: Polska Agencja Rozwoju Przedsiębiorczości.

Jas, M. i Łysak, K. (2009). Fundusze unijne dla oświaty: Jak budować programy rozwojowe szkół, by edukacja była skuteczna, przyjazna i nowoczesna. Warszawa: Fundacja Fundusz Współpracy.

Juchnicka, M. (red.) (2015). Czas na staż, dobre praktyki dualnego systemu kształcenia w branży turystycznej. Białystok: BFKK.

Komunikat Komisji do Parlamentu Europejskiego, Rady, Rady Europejskiej, Europejskiego Komitetu Ekonomicznospołecznego i Komitetu Regionów „Pracując wspólnie na rzecz młodych Europejczyków - Wezwanie do działania w sprawie bezrobocia osób młodych". Bruksela, 19.06.2013.

Krajowa Konferencja Zespołu Ekspertów ECVET „Edukacja z praktyką - partnerstwo na rzecz dualnego kształcenia zawodowego, Warszawa, 20 listopada 2017.

Myszka, S. (2009). Kierunki zmiany w rozwoju kształcenia zawodowego i ustawicznego w Polsce, Szkoła zawodowa szkołą pozytywnego wyboru, innowacyjnej wiedzy, umiejętności i kompetencji. Biuletyn Informacyjny Samorządowego Centrum Edukacji w Tarnowie, nr 19: 88-89.

Rozporządzenie Ministra Edukacji Narodowej z dnia 11 stycznia 2012 r. Dz. U z dnia 16 maja 2014 r., poz. 622, tekst jednolity, $\$ 3$ pkt 2.

Rozporządzenie Ministra Edukacji Narodowej z dnia 31 marca 2017 r. w sprawie podstawy programowej kształcenia w zawodach. Dz. U. 2017, poz. 860.

Rozporządzenie Ministra Edukacji Narodowej z dnia 7 października 2009 r., w sprawie nadzoru pedagogicznego. Dz. U. 2009, nr 168, poz. 1324.

Symela, K. (2009). Modułowe kształcenie zawodowe w Polsce - elementy diagnozy. Warszawa: KOWEZiU.

Ustawa z dnia 14 grudnia 2016 r. Prawo oświatowe. Dz. U. 2017, poz. 59.

Ustawa z dnia 14 grudnia 2016 r. Przepisy wprowadzające ustawę Prawo oświatowe. Dz. U. 2017, poz. 60 .

Ustawa z dnia 20 kwietnia 2004 r. o promocji zatrudnienia i instytucjach rynku pracy. Dz. U. 2004, nr 99, poz. 1001 z poźn. zm. 
Oficyna Wydawnicza SGH - Szkoła Główna Handlowa w Warszawie 02-554 Warszawa, al. Niepodległości 162

www.wydawnictwo.sgh.waw.pl

e-mail: wydawnictwo@sgh.waw.pl

Projekt okładki

ADYTON

Skład i łamanie

DM Quadro

Druk i oprawa

QUICK-DRUK s.c.

Zamówienie 76/VI/18 